九州大学学術情報リポジトリ

Kyushu University Institutional Repository

Studies on the alloplasmatic effect in tribe Brassiceae : II. Several conspicuous characteristics appeared in the carinatacytoplasmic pekinensis plant

Iwasa, Shoichi

Horticultural Laboratory, Department of Agriculture, Kyushu University

https://doi.org/10.5109/22702

出版情報: 九州大学大学院農学研究院紀要. 12 (4)，pp.213-228，1963-08. Kyushu University バージョン：

権利関係 : 


\section{Studies on the alloplasmatic effect in tribe Brassiceae II. Several conspicuous characteristics appeared in the carinata-cytoplasmic pekinensis plant*}

\section{Shoichi IWASA}

In nucieus-substituted plants produced by successive backcrossings various specific characters ascribable to an alloplasmatic effect have been frequently observed (e.g. Lein (1948) in Secale, Clayton (1950) in Nicotiana, Kihara (1951) in Aegilops, Mizushima and Katsuo (1958) in Brassica, Michaelis (1954) in Epilobium, Fukasawa (1959) in Triticum, etc.). In one of those studies in Epilobium a number of characteristic features, such as described as follows, were noticed and attributed to the disturbance of interactions between cytoplasm and genes: certain lethal or sterile character, many abnormal morphology in stems, leaves and flowers, heterotic growth responses, certain differences in cytoplasmic viscosity and permeability, different sensitivity to poisons and fungi, different enzymatic activity, different optima of temperatures, light, and of day-length conditions for growing, etc. Those variation ranges brought about by the alloplasmatic effect were not much narrower as compared with those caused by the gene mutations (Michaelis, 1951).

With the above examples, the manifestations of the effect of allocytoplasm have been highiy complicated for their extensive variations and their sensitive responses towards the changes in environments, so that whether a particular phenomenon occurring in a certain hybrid or in its progeny is of cytoplasmic, or not, can not be determined without the results of adequate observations gained with the $F_{1}$ plants raised by the reciprocal crosses and with the nucleus-substituted plants produced by the successive backcrosses.

In pekinensis plants having carinata's cytoplasm (in abbr., ca.

* Contribution from the Horticultural Laboratory, Faculty of Agriculture. Kyushu University. 
pekinensis plants) the author has found out several conspicuous characters, such as chlorophyll deficiency, some alterations in the form of leaves and flowers, and growth disturbances to some extent, being duly ascribable to the discordance between the carinata's cytoplasm and the pekinensis' nucleus, as will be described elsewhere in the following. The pedigrees of these ca-pekinensis plants which were taken up for investigation were those from $\mathrm{B}_{3} \mathrm{~F}_{4}{ }^{*}$ (1953) through $\mathrm{B}_{8} \mathrm{~F}_{11}$ (1960), being produced by the manner reported in the previous paper of this series (Iwasa, 1963).

Cytologically, the ca-pekinensis plants examined were normal in the meiotic divisions of PMCs and invariably showed $10_{\mathrm{rl}}$ at metaphase-I.

The author wishes to express his sincere gratitude to Prof. Dr. E. Fukushima of Kyushu University for his guidance throughout the course of this investigation and revision of the manuscript.

\section{RESULTS}

\section{Morphological alterations}

The ca-pekinensis plants were more or less different in their forms of leaves and flowers from normal pekinensis plants and the grade of these differences became increased or decreased according to the conditions in which the plants have been grown. The two different forms of $F_{1}$ plants, therefore, could be produced from the crosses between the ca-pekinensis plants and normal pekinensis ones and compared in details under the same environment.

Table 1. Frequency distribution of leaf shape indexes in $F_{1}$ plants obtained reciprocally. (1955)

\begin{tabular}{|c|c|c|c|c|c|c|c|c|}
\hline \multirow{2}{*}{$F_{1}$ cross combination } & \multicolumn{6}{|c|}{ Index (length/width) } & \multirow{2}{*}{$\begin{array}{l}\text { Mean } \\
\text { index }\end{array}$} & \multirow{2}{*}{$\begin{array}{l}\text { Number of } \\
\text { plants used }\end{array}$} \\
\hline & 1.2 & 1.3 & 1.4 & 1.5 & 1.6 & 1.7 & & \\
\hline Normal pehinensis $\times \mathrm{B}_{4} F_{5}$ & 6 & 1 & 6 & 7 & -- & - & 13.7 & 20 \\
\hline $\mathrm{B}_{4} \mathrm{~F}_{5} \times$ normal pekinensis & $\cdots$ & $\cdots$ & 1 & 9 & 8 & 1 & 15.5 & 19 \\
\hline
\end{tabular}

1. The form of leaves. The largest and the next largest leaves in the $F_{1}$ plants were measured of their lengths and widths when the plants were grown up to the bolting stage of growth in the greenhouse. Table 1 shows various length-width ratios of leaves (the leaf shape indexes). The result of measurements disclosed clearly that the indexes

* $\mathrm{B}_{3} \mathrm{~F}_{4}$ denotes the fourth generation hybrid strain derived through three times of backcrossings. 
showed the increasing tendencies because of the cytoplasmic effect to the $F_{1}$ plants having carinata's cytoplasm (in abbr., $c a-F_{1}$ plants).

2. The size of flowers. As in the form of leaves the size of flowers in the $c a \cdot F_{1}$ plants was a little smaller than that in the $F_{1}$ plants having pekinensis' cytoplasm (in abbr., pe-F, plants). And moreover, the flowers were more or less fainter in color in the former plants than in the latter. The measurements of flowers were made with the $F_{1}$ plants, half of which was grown continuously in the greenhouse and other half had been transferred to the nursery field from the greenhouse in October and grown there. The length and width of petals were measured with flowers on the next day of their full-bloom (Table 2). They were usually smaller in sizes with the $c a-\mathrm{F}_{1}$ plants than with the $p e-\mathrm{F}_{1}$ plants, i.e., 10 per cent smaller in the plants under the greenhouse condition and 20--30 per cent smaller in the nursery field, respectively. This fact will show that the effect of carinata cytoplasm in these $c a-\mathrm{F}_{1}$ forms can be witnessed by its in. tensity depended upon the environmental conditions of the growing.

Table 2. Comparison of petal sizes in $\mathrm{F}_{1}$ plants obtained reciprocally. (1955)

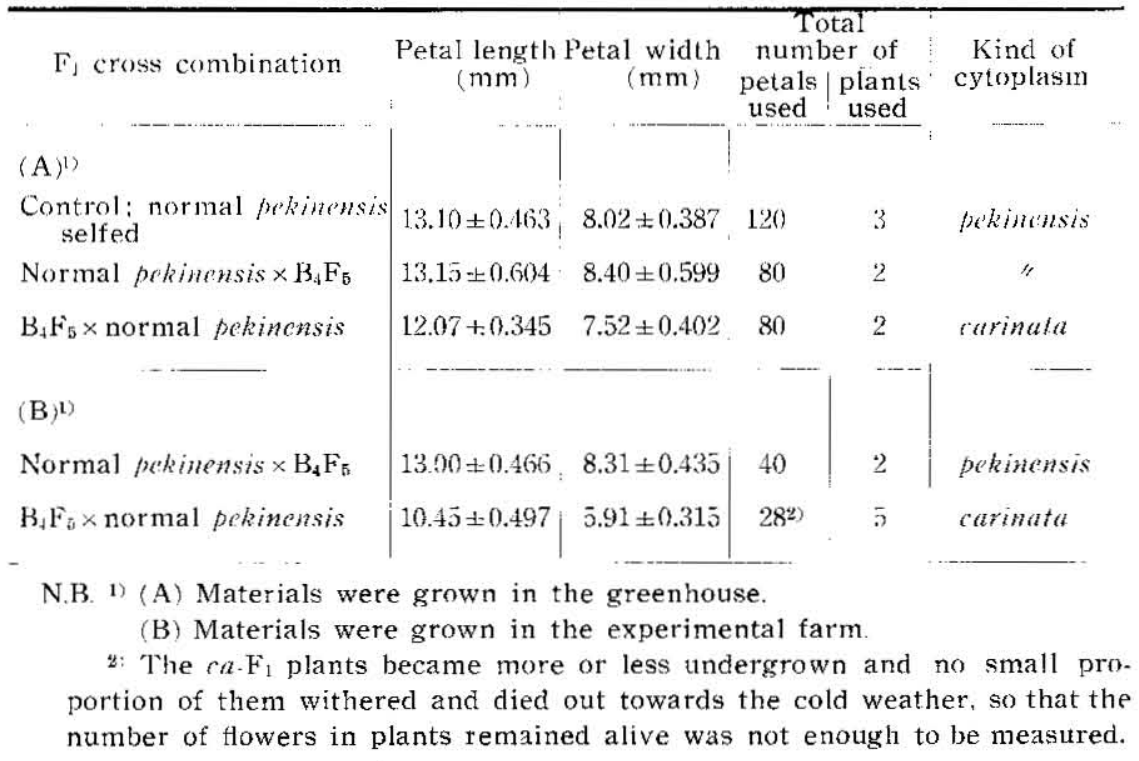

\section{Disturbances in growth}

The ca-pekinensis plants grown up from seeds germinated quite normally and developed at the early stage several foliage leaves showing conspicuous chlorophyll deficiency, being, in consequence, undersized in that stage of growth. Fig. 3--A shows two kinds of 
pekinensis plants, i.e., the normal and the carinata-cytoplasmic ones, the latter being undergrown and chlorophyll-deficient at an early growth stage. Table 3 is compiled from data of comparison of ca-pekinensis plants and normal pekinensis plants in their early stage of growth in the greenhouse and as weil as in the experiment farm. The average size of ca-pekinensis plants attained to the 50 per cent and to the only 20-30 per cent of that of normal pekinensis plants, respectively,

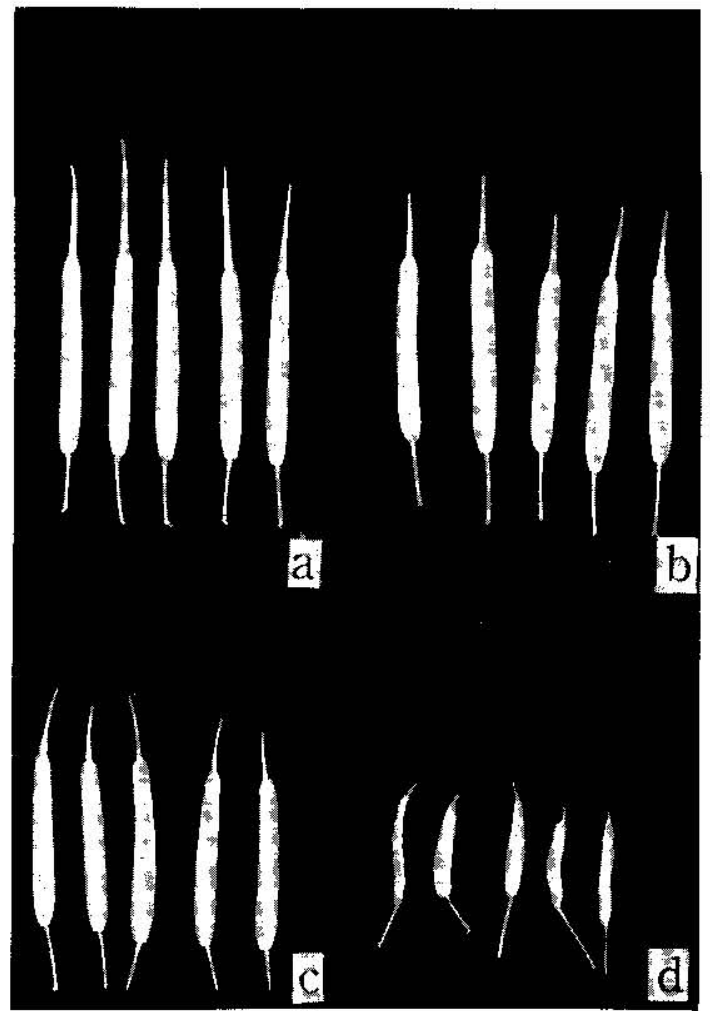

Fig. 1. Comparison of siliques set between different $F_{1}$ strains raised reciprocally and between the different growth con. ditions. (1955)

a; $F_{1}$ plants having pekinensis' cytoplasm, grown in the greenhouse.

c; ibid., grown in an open field.

$\mathrm{b} ; \mathrm{F}_{1}$ plants having carinata's cytoplasm, grown in the greenhouse.

d; ibid., grown in an open field.

corresponding to the cultural conditions, such as in the greenhouse and as in the experiment farm. Towards the middle of their growing stages the number of ca-pekinensis plants in a nursery bed in the ex- 
ment farm became to be reduced to less than half their original number. And thus in November when the plants were just to be transplanted, those remaining nursery plants, as a general rule, looked barely alive. But those ones kept in the greenhouse condition became, in contrast, growing up steadily towards their maturation and approaching also to the normal sizes of intact pekinensis plants. Fig. 1 shows some siliques from two kinds of $F_{1}$ plants which were raised reciprocally and cultured differently, i.e., some plants in the greenhouse and the others in an open field. The siliques produced in $p e-F_{1}$ plants were quite uniform in size, no matter whether the $F_{1}$ plants had grown up in the greenhouse (a) or in an open field (c), while those in $c a-\mathrm{F}_{1}$ plants were either identical or much more smaller in size than the normal according as the $F_{1}$ plants had grown up in the greenhouse (b) or in an open field (d). The situation was practically the same with the height of stems, i.e., the stems became half or more than half of the control height when $c a \cdot F_{1}$ plants had grown in an open field.

Table 3. Comparison of young seedling plants between carinata-cytoplasmic pekinensis and normal pekinensis. (1953)

\begin{tabular}{|c|c|c|c|c|c|c|}
\hline $\begin{array}{l}\text { Material plants and } \\
\text { their cultural con- } \\
\text { ditions. }\end{array}$ & $\begin{array}{c}\text { Maxim } \\
\begin{array}{c}\text { Length } \\
(\mathrm{cm})\end{array}\end{array}$ & $\begin{array}{l}\text { leaf } \\
\text { Width } \\
\text { (cm) }\end{array}$ & $\begin{array}{l}\text { Number of } \\
\text { spread } \\
\text { leaves }\end{array}$ & $\begin{array}{c}\text { Number of } \\
\text { chlorophyll- } \\
\text { defected } \\
\text { leaves }\end{array}$ & $\begin{array}{l}\text { Total nu } \\
\text { of plants }\end{array}$ & $\begin{array}{l}\text { 1mber } \\
\text { s used }\end{array}$ \\
\hline \multicolumn{7}{|l|}{ In the greenhouse: } \\
\hline $\begin{array}{l}\text { Normal control peki- } \\
\text { nensis }\end{array}$ & 14.6 & 7.7 & 5.1 & - & 20 & \\
\hline $\mathrm{B}_{3} \mathrm{~F}_{4}$ & 8.3 & 4.2 & 5.4 & $\quad \stackrel{4.1}{\sim}++)$ & 20 & \\
\hline \multicolumn{7}{|c|}{ In the experimental farm: } \\
\hline $\begin{array}{l}\text { Normal control peki. } \\
\text { nensis }\end{array}$ & 13.2 & 5.5 & 5.0 & $\cdots$ & 40 & \\
\hline$B_{3} F_{4}$ & 3.5 & 2.0 & 4.6 & $\begin{array}{c}4.6 \\
(+++t)\end{array}$ & 20 & \\
\hline
\end{tabular}

\section{Chlorophyll deficiency}

The most conspicuous character in the ca-pekinensis plants was chlorophyll deficiency, as reported in the previous paper (Iwasa, 1963). The condition in which many ca-pekinensis plants were grown during the period of from 1952 through 1961 and the extent of chlorophyll deficiency developed in each plant are shown in Table 4. The extreme case of this defect was noticed in the plants grown during the period of from 1957 through 1958. When seeds were sown in January in the cold glasshouse, and they were allowed under the covering until the germination, their germination attained 98 per cent. The 
yellowish-white cotyledons expanded did not turn out to be green at all, and the next developed foliage leaves of from the first to the third also remained in defective condition until the middle of February,

Table 4. Appearances of chiorophyll deficiency in the carinata-cytoplasmic pekincnsis plants and their respective growth responses.

\begin{tabular}{|c|c|c|c|c|c|c|c|c|c|c|c|c|}
\hline \multirow{2}{*}{ Strain } & \multirow{2}{*}{ Year } & \multicolumn{7}{|c|}{ Month } & \multirow[b]{2}{*}{ Apr. } & \multirow[b]{2}{*}{ May } & \multirow{2}{*}{\multicolumn{2}{|c|}{ 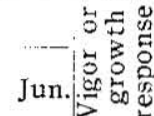 }} \\
\hline & & Sep. & Oct. & Nov. & Dec. & Jan. & Feb. & Mar. & & & & \\
\hline $\mathrm{B}_{3} \mathrm{~F}_{4}$ & $1952-1953$ & $(+4$ & - & $-)$ & ++ & $+4+1$ & $+t+$ & ++ & + & & & \\
\hline \multirow{4}{*}{$\mathrm{B}_{4} \mathrm{~F}_{6}$} & & $(+1)$ & - & - & + & + & - & - & $-\overrightarrow{1}$ & & & $\Lambda$ \\
\hline & $19 \overrightarrow{\mathbf{j} 3}-1954$ & & $(t+$ & $-)$ & t & ++ & $+1+1$ & ++ & 1 & & & $\mathrm{C}$ \\
\hline & & & $(t+$ & - & + & - & - & - & $-)$ & & & 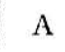 \\
\hline & & & $+t+$ & + & + & ++ & +++ & +4 & + & & . & $\mathrm{C}$ \\
\hline \multirow[t]{2}{*}{$\mathrm{B}_{6} \mathrm{~F}_{0}$} & $1954-1955$ & $(+++$ & + & 1) & ++ & +++ & ++ & +4 & 14 & & & C \\
\hline & & $(t++$ & $-\quad-$ & 1 & $i$ & - & - & - & $-)$ & & & A \\
\hline $\mathrm{B}_{6} \mathrm{~F}_{7}$ & $195 \vec{\jmath}-1956$ & $(+++$ & $-\ldots$ & - & + & + & + & + & $-)$ & & & A \\
\hline $\mathrm{B}_{6} \mathrm{~F}_{8}$ & $1956-1957$ & $+t+$ & - & - & $++\cdot+$ & $(1+$ & + & + & $\cdots$ & & & 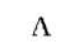 \\
\hline $\mathrm{B}_{0} \mathrm{~F}_{9}$ & $|1957-1958|$ & & & & & $(t+t+4$ & $+++-)$ & & & & & \\
\hline $\mathrm{B}_{7} \mathrm{~F}_{10}$ & $1958-1959$ & & & & & & $(t+t$ & 11 & $+t$ & - & $--1)$ & B \\
\hline $\mathrm{B}_{8} \mathrm{~F}_{11}$ & $1959-1960$ & & & $1++$ & $+j$ & + & 1 & + & +1 & & & D \\
\hline $\mathrm{B}_{9} \mathrm{~F}_{12}$ & $1960-1961$ & $(++$ & - & - & -1 & +4 & ++ & ++ & + & & & D \\
\hline
\end{tabular}

N.B. $-\sim+++$ : The degrees of chlorophyll deficiency, with whole the plants used.

Figures in ( ) indicate that the plants are growing in the heated greenhouse condition (about $10^{\circ} \mathrm{C}$ or higher), and figures in (f) indicate that the plants are growing in the cold glasshouse condition. Figures without parentheses indicate that the plants are growing in the open field.

A : All the plants grew up to their full maturity.

B: About half or more than half of plants grew up to their full maturity.

C: Less than half of plants grew up to their full maturity.

D: Any one plant did not grew up to its maturity.

and all the plants became to die out rapidly in succession. Even under the greenhouse condition those plants showed sometimes very slight chlorophyll deficiency, i.e., some of their leaves were somewhat splotched with white color on their margin of blades.

Chlorophyll deficiency was observed, in turn, in various degrees with the different individuals (Fig. 2, a d). This character, however, 
did not appeared throughout the processes of nucleus-substitution with the aneuploid forms composed of from 21 through 36 somatic chromosomes and it became to be recognized barely on the first leaf of a young $2 \mathrm{n}=21\left(10_{1 \mathrm{i}}+1_{\mathrm{I}}\right)$ plant (Fig. 2 , e- $-\mathrm{g}$ ).

Examined under a microscope of the cross sections of chlorophylldeficient leaves, each variegated part was found to have in it a number of large-sized cells containing chloroplasts and intermixed with irregularly arranged chloroplastless cells. The chloroplasts contained were identical in form with those found in a normal pekinensis plant.

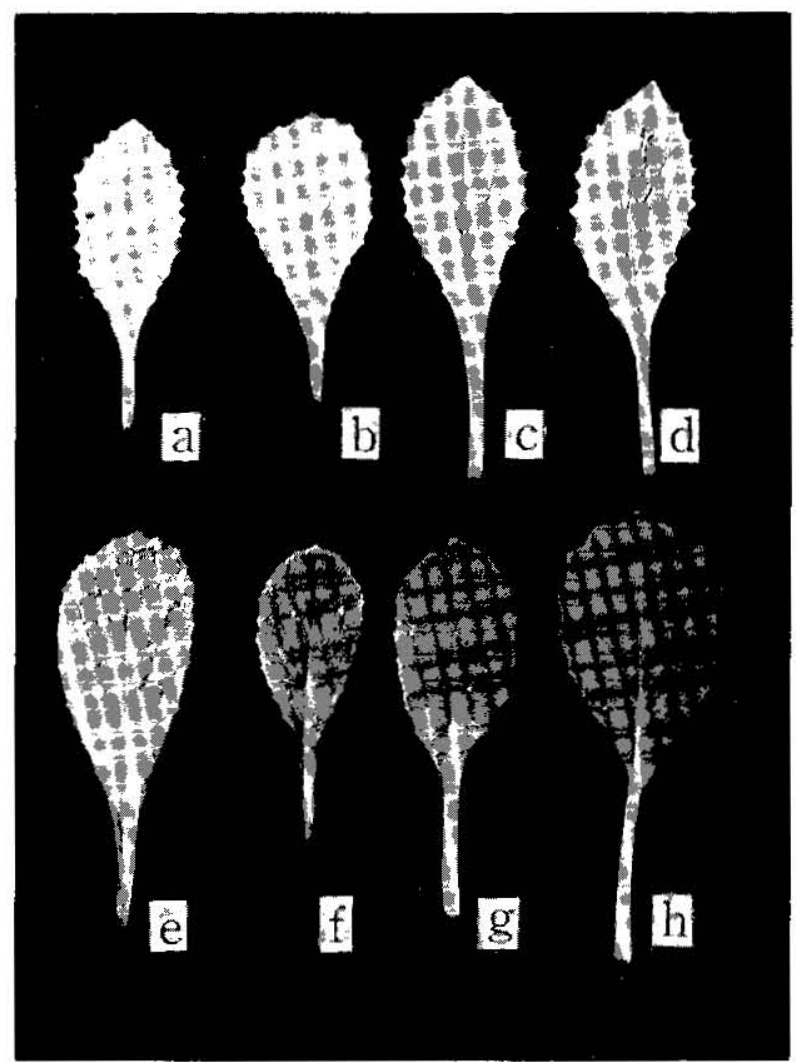

Fig. 2. Various degrees of chlorophyll-deficiency appearing in the first foliage leaves. (1952)

$\mathrm{a}-\mathrm{d}$; carinata-cytoplasmic pekinensis plants.

$\mathrm{e}-\mathrm{g}$; carinata-cytoplasmic $2 \mathrm{n}=21$ plants.

$\mathrm{h}$; normal pekinensis plant.

IV. Biochemical analysis of chlorophyll-deficient leaves

1. Quantitative analysis of chlorophylls. To $50-70 \mathrm{mg}$ of fresh 
chlorophyll-deficient leaves was mixed an adequate volume of 80 per cent solution of acetone; the mixture was ground in a mortar and filterd for extraction of chlorophylls; the optical density of the extract obtained was determined by means of Beckman's spectrophotometer; for the quantitative determination of the extracted chlorophylis G. Mackinney's formula (1941) was used:
$\mathrm{D}_{663}=82.04 \mathrm{Ca}+9.27 \mathrm{Cb}$
$\mathrm{D}_{t: 5}=16.75 \mathrm{Ca}-45.6 \mathrm{Cb}$
$\mathrm{D}=$ optical density; $\mathrm{Ca}=$ chlorophyll $a ; \mathrm{Cb}=$ chlorophyll $-b$.

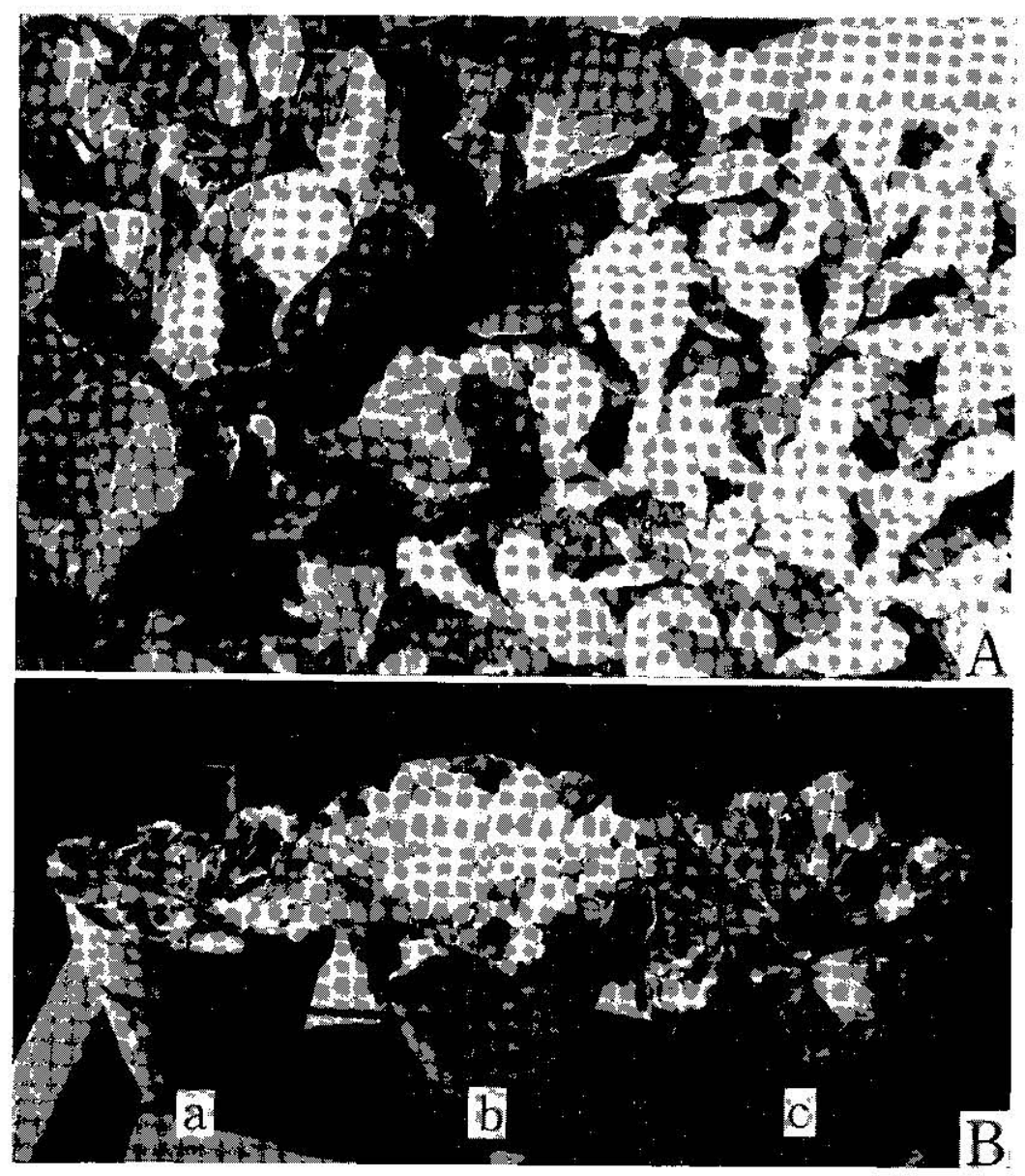

Fig. 3. A: Chlorophyll deficiency and retarded growth responses appeared in the younger seedlings of carinala-cytoplasmic pckinensis plants (right), compared with the control pekinensis plants (left). (1960)

B: General appearances of chlorophyll deficiencies under the low temperature environment. (1955)

a) $2 \mathrm{n}=21$ plant having carinala's cytoplasm. b; $2 \mathrm{n}=20$ plant having carinata's cytoplasm. c; $2 \mathrm{n}=20$ plant (normal pekinensis). 
The quantitative analysis of carotenoid was made simultaneously. The leaves used as samples were gathered from the potted plants which were cultured at first in the greenhouse and transferred into the open field in December to render them prominently deficient in chloro. phyll appearance by the low temperatures (see Fig. 3-B). The fully expanded cotyledons used as samples were collected from the seedlings germinated at low temperatures. Normal pekinensis plants and $\mathrm{ca}$. $\left(10_{\mathrm{II}}+1_{\mathrm{I}}\right)$ plants were used as controls.

By the use of the foregoing materials and methods the results shown in Table 5 were obtained. In this Table three samples (1), (2) and (3) of the leaves of the ca-pekinensis plant are representing those highly chlorophyll-deficient (1), those moderately so (2), and those barely so and nearly normal (3). As may be evident from Table 5, in capekimensis plants the outward sign of chlorophyll deficiency was found to keep step in its variation with the total amount of the chlorophyll contained. This was more actually the case with chlorophyll $b$ than with chlorophyll- $a$, the $a: b$ ratio varying much more remarkably. The carotenoid contained was a trifle smaller in quantity in chlorophylideficient leaves than in normal ones, so that the quantitative variation of this substance was far less conspicuous than that of chlorophylls in either kind of the leaves while the relative value of carotenoid with chlorophylls in chlorophyll-deficient leaves was higher than that in normal ones. $C a-\left(10_{\mathrm{Ir}}-1_{\mathrm{I}}\right)$ plants revealed no sign of chlorophyll deficiency, as shown in Fig. 3-B, and their chlorophyll content was equal to that of normal pekinensis plants, though their carotenoid content was increased above that of normal pekinensis ones.

Table 5. Contents of chlorophylis and carotenoid in the foliage leaves of carinata-cytoplasmic pekinensis plants. (mg/g in fresh weight) (1956)

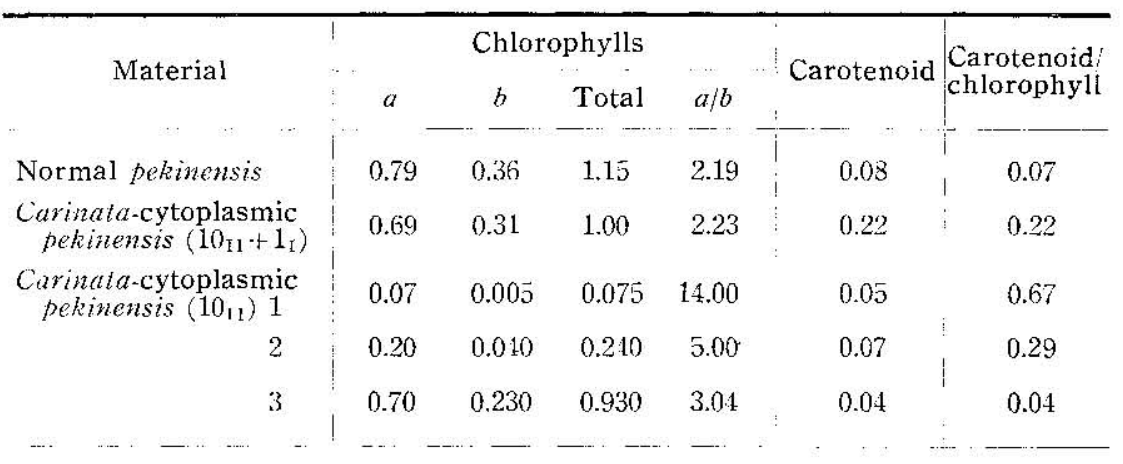

The analytic results obtained with their cotyledons (See Table 6) were quite similar in general tendency as in their expanded foliage leaves as shown in Table 5 . 
The results mentioned above could sufficiently demonstrate that the extra-chromosome, which was derived from the carinata, restored the chlorophyll deficiency and increased the carotenoid content in the ca- $\left(10_{\mathrm{II}}+1_{\mathrm{I}}\right)$ plant.

Table 6. Contents of chlorophylls and carotenoid in the cotyledons of carinatacytoplasmic pekinensis plants. (mg/g in fresh weight) (1956)

\begin{tabular}{|c|c|c|c|c|c|c|}
\hline \multirow{2}{*}{ Material } & \multicolumn{4}{|c|}{ Chlorophylls } & \multirow{2}{*}{ Carotenoid } & \multirow{2}{*}{$\begin{array}{l}\text { Carotenoid } \\
\text { chlorophy] }\end{array}$} \\
\hline & $a$ & $b$ & Total & $a / b$ & & \\
\hline Normal pekinensis & 0.40 & 0.11 & 0.51 & 3.64 & 0.14 & 0.28 \\
\hline $\begin{array}{l}\text { Carinata } \text {-cytoplasmic } \\
\text { pekinensis }\left(10_{11}+1_{1}\right)\end{array}$ & 0.66 & 0.27 & 0.93 & 2.44 & 0.25 & 0.27 \\
\hline$\left(10_{11}\right)$ & 0.073 & 0.024 & 0.097 & 3.04 & 0.07 & 0.79 \\
\hline
\end{tabular}

N.B. These materials were grown under low temperature $\left(\right.$ ca. $\left.5^{\circ} \mathrm{C}\right)$ conditions.

2. The quantitative variation in chlorophyll content with voung plants. The chlorophyll deficiency of ca-pekinensis plants, though it depended upon the thermal condition in which the plants were grown (see Table 4), appeared always whenever the plants were young. Fig. 4 shows how the extents of chlorophyll deficiency in the ca-pekinensis plants growing in a favorable thermal condition varied during the period of 35 days counted from the day when the plants began to germinate. The amounts of chlorophylls given in the figure were measured by the method described in the preceding page. The chlorophyll content of the young ca-pekinensis plants began to show marked increase at the approximate date of from the 10th to 20th day of the germination. And the cotyledons showed also the similar increasing of their chlorophyll contents with a remarkable progression under the ordinary thermal condition, excepting the adverse low temperature conditions as shown in Table 6 .

3. Paper-chromatographic examinations on the chlorophyll deficiency. The leaves used as materials in this examination were, (1) those very young and showing usual chlorophyll deficiency, (2) those highly chlorophyll-deficient ones, (3) those moderately deficient ones, and, in addition, (4) those of normal pekinensis plants as the control. Each sample of those leaves was treated with an 80 per cent solution of acetone for extraction of chlorophylls; to the extract obtained was added ethyl-alcohol and a large volume of 20 per cent solution of $\mathrm{NaCl}$; the chlorophylls in the mixture were removed into ether, washed with water, and condenced under reduced pressure; the concentrated solutions obtained were spotted on the paper and were separated by onedimentional ascending paper chromatography. The filter-paper and the 
solvent used were Tôyô filter-paper No. 51 and a mixture of toluene (100 parts) and ethyl-alcohol (1 part). The paper sheets were developed

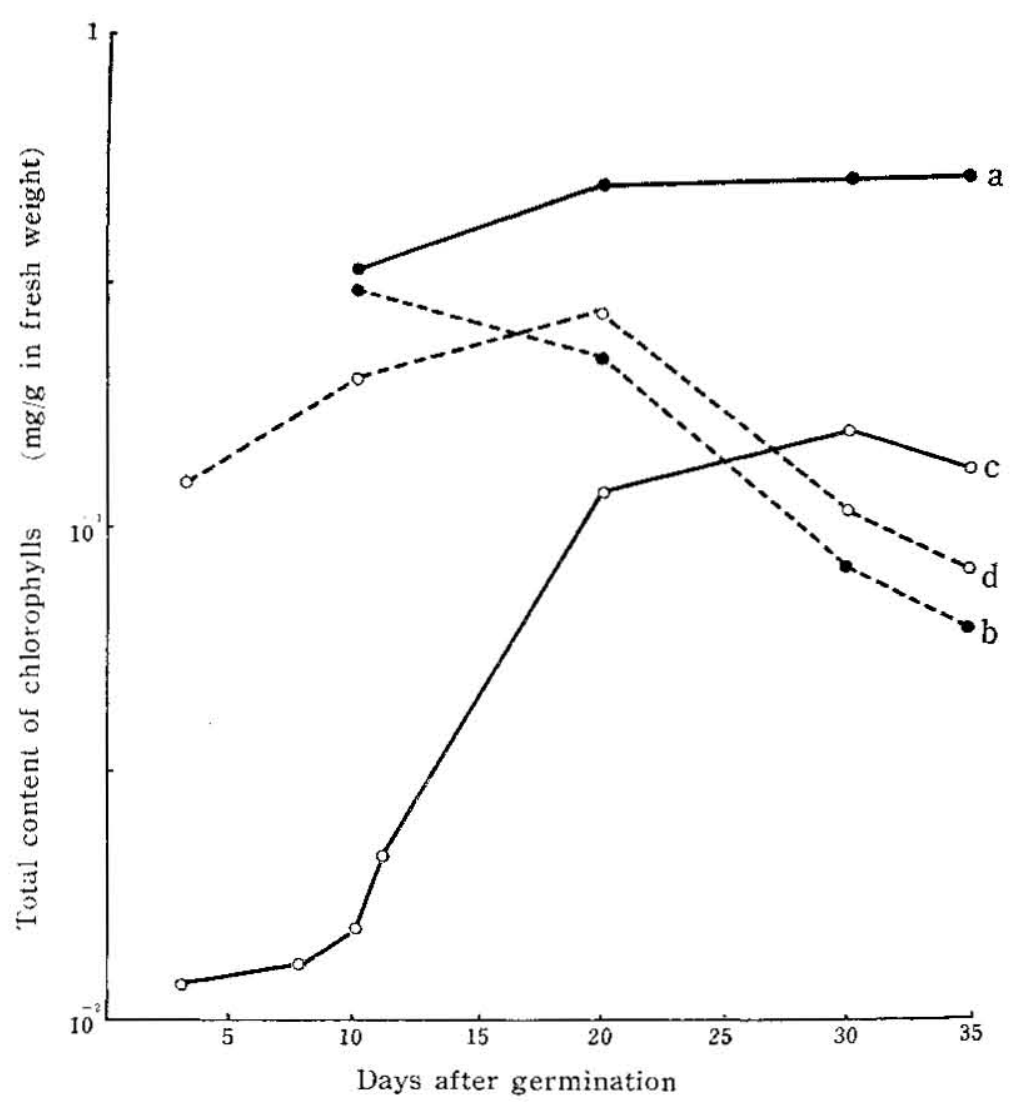

Fig. 4. Various trends in contents of total chlorophylls with different kinds of young leaves at the very eariy growing stage. (1956)

a; foliage leaves of normal pekinensis plants.

c; foliage leaves of carinata-cytoplasmic pekinensis plants.

b; cotyledons of normal pekinensis plants.

d; cotyledons of carinata-cytoplasmic pekinensis plants.

in the dark. After drying the chromatograms, they were examined under an ultraviolet light having main emission at $3600 \hat{\mathrm{A}}$ and detected as the fluorescent patterns. Those patterns obtained varied more or less as follows with the sample used: with sample (1) neither chlorophyll- $a$ nor $-b$ was detected at all, but a fluorescent spot remained intact at the original place; with sample (2) chlorophyll- $a$ could be detected exclusively, and a fluorescent spot remained also at the original place; with sample (3) chlorophyll- $a$ and a barely traceable quantity of 
chlorophyll- $b$ was detected, no fluorescent spot being retained at the original place; with sample (4) a marked amount of both chlorophyll-a and $-b$ was detected, but no fluorescent spot remained at the original place.

These ascertained facts appears to indicate that the occurrence of chlorophyll deficiency in ca-pekinensis plant is mainly due to some obstruction of the process of chlorophyll formation. It should be hoped that the author's work in this line of studies will throw some light on these problems.

\section{Fertility}

The $\mathrm{B}_{3} \mathrm{~F}_{4}$ plants, being equal to the first generation of ca-pekinensis plants, were nearly as same as normal pekinensis plants in their fertility (99.1 per cent in pollen-fertility; 51.5 per cent in seed-fertility) when grown in the greenhouse. However, when they were grown in the experimental farm they soon died out entirely. In order to see how the fertility of these plants were affected by the different environmental conditions, with the plants of $B_{4} F_{5}$ and $B_{5} F_{v}$ generations the fertility was examined under the growth conditions as shown in Table 4 (1954-1955). Irrespective of their origins, all the plants grown in the greenhouse were about equally high in their pollen- and seed-fertilities,

Table 7. Comparison of pollen-and seed-fertilities in $F_{1}$ plants obtained reciprocaliy. (1905)

\begin{tabular}{|c|c|c|c|c|c|c|}
\hline \multirow[b]{3}{*}{$\begin{array}{c}F_{1} \text { cross } \\
\text { combination }\end{array}$} & \multicolumn{6}{|c|}{ Cultural condition } \\
\hline & & Greenhouse & & & Open field & \\
\hline & $\begin{array}{l}\text { Fertile } \\
\text { pollen- } \\
\text { grains } \\
(\% / 0)\end{array}$ & $\begin{array}{c}\text { Viable seeds } \\
\text { per placentae } \\
\text { developed } \\
(\%)\end{array}$ & $\begin{array}{l}\text { No. of } \\
\text { plants } \\
\text { used }\end{array}$ & $\begin{array}{c}\text { Fertile } \\
\text { pollen. } \\
\text { grains } \\
(\%)\end{array}$ & $\begin{array}{c}\text { Viable seeds } \\
\text { per placentae } \\
\text { developed } \\
(0)\end{array}$ & $\begin{array}{l}\text { No. of } \\
\text { plants } \\
\text { used }\end{array}$ \\
\hline $\begin{array}{l}\text { Control; normal } \\
\text { pekinensis }\end{array}$ & 99.7 & $52.6-71,2-80.2^{1)}$ & 6 & 99.3 & $71.3-76.5-78.9^{1)}$ & 5 \\
\hline $\begin{array}{l}\text { Normal pekinensis } \\
\times \mathrm{B}_{3} \mathrm{~F}_{4}\end{array}$ & 98.6 & $76 . \overline{5}-83.9-92.1$ & 3 & - & $83.8-86.7-90.4$ & 6 \\
\hline$\underset{\times \mathrm{B}_{4} \mathrm{~F}_{5}}{\stackrel{\text { Normal pekinensis }}{ }}$ & - & $52.2-69.8-82.3$ & 5 &.- & $7 \overline{3} .8-82.6-89.5$ & $\overline{5}$ \\
\hline $\begin{array}{l}\mathrm{B}_{3} \mathrm{~F}_{4} \times \text { normal peki } \\
\quad \text { nensis }\end{array}$ & 99.0 & $56.5-73 . \overline{3}-88.0$ & 3 & 98.3 & $37.6-44.0-50.4$ & 2 \\
\hline $\begin{array}{l}\mathrm{B}_{4} \mathrm{~F}_{5} \times \text { normal peki- } \\
\quad \text { nensis }\end{array}$ & - & $54.0-74.4-80.7$ & 8 & $\ldots$ & $5.0-30.6-51.6$ & 7 \\
\hline
\end{tabular}

N.B. ${ }^{2)}$ minumum-average-maximum values.

but in the experimental farm the normal pekinensis and $p e-F_{1}$ plants were much more fertile than in the greenhouse, while $c a-\mathrm{F}_{1}$ plants showed rather normal pollen-fertility and notably low seed-fertility 
(Table 7). Similar phenomena of degraded fertility were also met with among plants grown densely crowded in narrow spaces throughout their growing. As shown in Table 8, comparative examinations were caried out with the following plants; (1) the normal pekinensis plants grown out of seeds sown at $3 \mathrm{~cm}$ apart in a seedling box, (2) the $c a$ pekinensis plants grown under the same condition as the plants (1),

Table 8. Variation of seed-fertility of carinata-cytoplasmic pekinensis plants under the diferent cultural conditions. (1959)

\begin{tabular}{|c|c|c|c|c|}
\hline $\begin{array}{c}\text { Cultural condition and } \\
F_{1} \text { cross combination }\end{array}$ & $\begin{array}{l}\text { Number of } \\
\text { seeds per } \\
\text { silique }\end{array}$ & $\begin{array}{l}\text { Number of } \\
\text { placentae } \\
\text { per silique }\end{array}$ & $\mid \begin{array}{l}\text { Viable seeds } \\
\text { per placentae } \\
\text { developed }(0 ; 0)\end{array}$ & $\begin{array}{l}\text { Number of } \\
\text { silique } \\
\text { examined }\end{array}$ \\
\hline $\begin{array}{l}\text { A) Densely crowded } \\
\text { box-culture: }\end{array}$ & & & $i$ & \\
\hline $\begin{array}{l}\text { Control; normal peki- } \\
\text { nensis }\end{array}$ & 15.1 & 22.9 & 65.9 & 26 \\
\hline $\mathrm{B}_{6} \mathrm{~F}_{9} \times$ normal pekinc $n$ sis & 2.4 & 24.7 & 9.7 & 19 \\
\hline $\begin{array}{l}\text { B) Ordinary pot cul. } \\
\text { ture: }\end{array}$ & & & & \\
\hline $\mathrm{B}_{0} \mathrm{~F}_{9} \times$ normal pokinensis & 12.2 & 23.2 & 52.6 & 22 \\
\hline
\end{tabular}

and (3) the ca-pekinensis plants grown under the ordinary pot-culture. The results of such examinations indicated that the plants (1) and (3) were exclusively much higher in their seed-fertility as compared with the plants (2), which became to be stunted in their growing, and resulted in bearing only a few siliques per plant.

As mentioned above, those harmful effects induced by the field and crowded culture towards the seed fertility of ca-pekinensis plants varied according to the degrees of retardation in their growth responses.

\section{DISCUSSION}

Chlorophyll deficiency, which is the most conspicuous characteristic arised through the alloplasmatic effect in the ca-pekinensis plants, was also noticed as such a specific character to some other plant forms, e.g., the Triticum durum plants having Aegilops ovata's cytoplasm (Fukusawa, 1957), and a certain interspecific hybrid in Oenothera (Schwemmle et al., 1938). It is well known that many nuclear genes in addition to cytoplasmic factors are concerned in various cases of chlorophyll deficiencies. Gene mutations related with this deficiency have been brought about rather frequently, either spontaneously or artificially (by means of radiations, chemical agents, etc.), indicating presumably that the process of formation of chlorophylls is highly 
complicated and may often be interfered with many different factors. Chlorophyll deficiency in ca-pekinensis plants is likely to arise from the carinala-cytoplasmic cffect disturbing a part of action of nuclear genes concerned with chlorophyll formation. This deficiency, however, did not appeared during the processes of nucleus-substitution with the carinata-cytoplasmic aneuploid forms composed of 21-37 somatic chromosomes and it became to be recognized barely on the $2 n=21$ plant. And this fact indicates beyond doubt that the extra-chromosome, which has originated from the carinata, contains a certain genes capable of partly undoing the effect of carinata cytoplasm. The detailed results as to the $c a-\left(10_{\mathrm{IL}}+1_{1}\right)$ plants will be presented in a separate paper.

The fact that the carinata-cytoplasmic effect represents various conspicuous appearances according to the unfavorable environmental conditions, i.e., the open field culture, the crowded growing, under the low temperatures, and various other adverse conditions, is quite concurring with the observations of Michaelis (1935) in Epilobium, where the phenotypic differences between $E$. hirsutum plants having $E$. hirsutum's cytoplasm and $E$. hirsutum plants having E. luteum's cyto. plasm became much exaggerated under unfavorable conditions, e.g., the cultivation using very small pots. Thus the phenomena like these may be regarded as one feature of the peculiar alloplasmatic effects.

Retarded growth and chlorophyll deficiency usually appeared closely connected together in the ca-pekinensis plants, not admitting any separate occurrence. It appears, however, that the retarded growth is unquestionably ascribable to the carinata-cytoplasmic effect alone in some cases, as may be duly presumed from the fact that the $c a-\left(10_{11}+1_{1}\right)$ plants revealed the retardation in growth without accompanying a definite sign of chlorophyll deficiency. Thus the assumption that the former character may necessarily result from the latter could not be held.

The ca-pekinensis plants did not exhibit, in turn, any sign of male sterility, a representative character effected alloplasmatically (e.g., Michael is (1933) in Epilobium, Clayton (1950) in Nicotiana, Kihara (1951) in Aegilops, and Fukasawa (1953) in Triticum), and could induce normal pollen-fertility even under adverse environmental conditions, being somewhat enfeebled in growth and correspondingly low in its seed-fertility. This decrease of seed-fertility may not be directly at. tributable to the alloplasmatic effect.

With the nucleus-substituted $B$. oleracea having $B$. nigra's cyto plasm, Mizushima and Katsuo (1953) reported that the nigra's cytoplasm appeared to inhibit the action of the self-incompatible genes contained in $c$ genome, composing the substituted nuleus in this form. The 
present ca-pekinensis plants appeared to be somewhat self-compatible, in contrast to the original $B$. pekinensis, and though the author's investigations have not yet been made sufficient to decide whether the cytoplasmic effect may or may not be operating in this circumstance.

\section{SUMMARY}

The pekinensis plant having carinata's cytoplasm, a product of nucleus-substitution, revealed conspicuous characters ascribable to an alloplasmatic effect. In this report is given an account of those characters.

1. The leaves were somewhat slender and the flowers were smaller-sized in this alloplasmatic plant as compared with a normal pekinensis plant.

2. The plant varied in the rate of its growth under different conditions, growing at a much reduced rate and revealing marked signs of chlorophyll deficiency under adverse conditions. Retarded growth and chlorophyll deficiency are so closely related to each other with this plant as to admit no separate occurrence. However, as a $\left(10_{11}, 1_{1}\right)$ plant having carinata's cytoplasm showed its retarded growth, not revealing a trace of chlorophyll deficiency, it may be safely asserted that the retarded growth is unquestionably ascribable to the carinata-cytoplasmic effect in this plant.

3. Morphological and biochemical investigations disclosed that, with the plants ranging nine generations $\left(B_{3} F_{4}-B_{4} F_{12}\right)$, chlorophyll deficiency, the most conspicuous character in those plants, was somewhat strengthened under strong light and low temperature conditions (about $5^{\circ} \mathrm{C}$ or lower), showing considerable variation in its manifestation from individual to individual. Chlorophyll-deficient leaves in those alloplasmatic plants contained no doubt chlorophylls in an insufficient quantity, and accompanied also the quantitative alterations resulted through the changes in ratio of the chlorophyll $a: b$ and that of chlorophyll: carotenoid. It was found on further examination that, in the $\left(10_{\mathrm{II}}+1_{\mathrm{I}}\right)$ plant having carinata's cytoplasm, the added extra-chromosome acted upon the carinata-cytoplasmic effect and redeemed the chlorophyll-defect, also increasing the carotenoid content.

4. The plant was normal in its pollen-fertility under any environmental conditions, and either almost normal or subnormal in its seedfertility according as it had been growing up in a greenhouse or under an adverse condition. As reduced seed-fertility was invariably attended with retarded growth in this plant, it seems that this decrease of seed-fertility may not be directly attributable to the alloplasmatic effect. 


\section{LLTERATURE CITED}

Clayton, E. E. 1950 Male sterile tobacco. Jour. Hered. $41: 170-175$.

Fukasawa, H. 1959 Nucleus substitution and restoration by means of successive backcrosses in wheat and its related genus Aegilops. Jap. Jour. Bot. 17: $55-91$.

Iwasa, S. 1963 Studies on the alloplasmatic effect in tribe Brassiceae, I. On the carinata-cytoplasmic Brassica pekinensis induced by the successive back. crosses. Jour. Fac. Agric. Kyushu Univ. 12: 201-212.

Kihara, H. 1951 Substitution of nucleus and its effects on genome manifestations. Cytologia 16: 177-193.

Lein, A. 1948 Über alloplasmatische Roggen (Roggen mit Weizenplasma). Züch. ter 19: 101-108.

Mackinney, G. 1941 Absorption of light by chlorophyll solutions. Jour. Biochem. $140: 315-322$.

Michaelis, P. 1933 Entwicklungsgeschichtlich-genetische Untersuchungen an Etilobium, II. Die Bedeutung des Plasmons für die Pollenfertilität des Epilobium luteum-hirsutum-Bastarde. Z. 1. A. V. 65: 1-71.

-... 1935 Erhohte Wachstumsintensität und Pirzresistanz durch Plasma. vererbung, sowie über die Bedeutung des Plasma bei Kreuzungschwierig. keiten. Züchter 7: 74-77.

- _- 1951 Interaction between genes and cytoplasm in Epilobium. Cold Spr. Har. Sym. Quan. Biol. XVI: 121-129.

- - 1954 Cytoplasmic inheritance in Epilobium and its theoretical significance. Advances in Genetics 6: 287-401.

Mizushima, U. and Katsuo, K. 1958 Elimination of self-incompatibility in the common cabbage, Brassica oleracea L., by means of substitution of nucleus. Proc. X. Internat. Cong. Genet. II : 191.

Schwemmle, J., Haustein, E., Sturm, J., and Binder, M. 1938 Genetische Unter. suchungen an Eu-Oenotheren, I-IV. Z. I. A. V. 75: 358-800. 